\title{
IMPROVING THE LEADERSHIP COMPETENCY OF PONDOK PESANTREN TEACHERS THROUGH GROWING LEADERSHIP TRAINING IN FACING THE CHALLENGES OF THE DIGITAL ERA
}

\author{
${ }^{1}$ Muhsin, ${ }^{2}$ S Martono, ${ }^{3}$ Kusumantoro, ${ }^{4}$ Ahmad Nurkhin, ${ }^{5}$ Abdul Hobar \\ 1,2,3,4,5 Universitas Negeri Semarang
}

\section{ARTICLE INFO}

Article History:

Received April, 09, 2021

Accepted June, 14, 2021

Available June, 302021

\section{Keywords:}

Kepemimpinan Bertumbuh,

Leadership Competence,

Boarding Schools

\begin{abstract}
Tenaga pengajar (ustadz dan ustadzah) di pondok pesantren menghadapi tantangan dalam pembinaan santri. Perkembangan teknologi informasi pada era revolusi industri 4.0 telah berdampak pada pola pendidikan pondok pesantren. Oleh karena itu, diperlukan pelatihan Kepemimpinan Bertumbuh untuk meningkatkan kompetensi kepemimpinan para asatidz. Program pengabdian kepada masyarakat ini bermitra dengan Yayasan Al Asror Patemon Gunungpati Semarang. Metode yang digunakan adalah Seminar Pendidikan Strategi Kepemimpinan Bertumbuh dalam Menghadapi Tantangan Era Digital. Kegiatan ini juga bekerjasama dengan LP3 UNNES yang telah menjadikan Yayasan Al Asror sebagai mitra. Kegiatan pengabdian dilaksanakan di aula Madrasah Aliyah (MA) Al Asror, pada hari Sabtu, 8 Agustus 2020. Kegiatan diawali dengan penandatanganan dokumen rencana pelaksanaan kegiatan antara FE UNNES dan Yayasan Al Asror sebagai tindak lanjut Kerjasama (MOU) antara UNNES dan Yayasan. Narasumber kegiatan adalah Plt. Wakil Rektor Bidang Kerjasama dan Perencanaan, Dr. Hendi Pratama, MA. yang memaparkan materi mengenai "Menguatkan Reputasi Pribadi dan Lembaga Al Asror". Narasumber kedua adalah Ketua LP3 UNNES, Dr. Ngabiyanto, M.Si. yang menyampaikan materi "Strategi Kepemimpinan Bertumbuh dalam Menghadapi Tantangan Era Digital". Peserta kegiatan sangat antusias mengikuti kegiatan ini. Hal ini tampak pada partisipasi peserta saat narasumber mengajak dialog langsung dengan peserta. Peserta juga sangat antusias pada sesi tanya jawab.
\end{abstract}

Teachers (ustadz and ustadzah) in boarding schools face challenges in the construction of students. The development of information technology in the era of industrial revolution 4.0 has had an impact on the pattern of boarding school education. Therefore, it is necessary to train "Kepemimpinan Bertumbuh" to improve the leadership competence of the asatidz. This community service program is partnered with Yayasan Al Asror Patemon Gunungpati Semarang. The method used is The Education Seminar of Growing Leadership Strategy in Facing the Challenges of the Digital Era. This activity also collaborates with LP3 UNNES which has made Al Asror Foundation as a partner. The service was held in madrasah Aliyah (MA) Al Asror hall, on Saturday, August 8, 2020. The activity began with the signing of a document on the implementation plan of activities between FE UNNES and Al Asror Foundation as a follow-up to the Cooperation (MOU) between UNNES and the Foundation. The speakers of the activity were Plt. Vice Rector for Cooperation and Planning, Dr. Hendi Pratama, MA. which presents material on "Strengthening the Personal Reputation and Institution of Al Asror". The second speaker was the Chairman of LP3 UNNES, Dr. Ngabiyanto, M.Si. who delivered the material "Leadership Strategy to Grow in Facing the Challenges of the Digital Era". Participants of the activity are very enthusiastic to participate in this activity. This is evident in the participation of participants when the speaker invites direct dialogue with the participants. Participants were also very enthusiastic at the question and answer session.

Address: L Building, Campus Sekaran, Gunungpati, Semarang, Indonesia, 50229

Correspondent Address:

Universitas Negeri Semarang

Email: ahmadnurkhin@mail.unnes.ac.id 


\section{INTRODUCTION}

Pesantren as an educational institution has its own characteristics, so that pesantren can be distinguished from other educational institutions that are non pesantren. The characteristics of pesantren are considered very unique by educational observers, ranging from the tradition, curriculum, education system, infrastructure, kiai leadership model, and also the lifestyle of the students who are very simple and prioritize togetherness (Faris, 2015).Santri and boarding schools have become an important part of the history of the nation and the country of Indonesia. The existence of students and boarding schools has contributed significantly to the life of the Indonesian people.

Boarding schools have become one of the important institutions to print people who have good morals and will be able to contribute in public life. The development of student behavior today shows a shift that demands attention from all parties. This is inseparable from the development of information technology, social media, and so forth. The development of industrial revolution 4.0 has had an impact on life in boarding schools. Communication patterns between students, students with alumni, students with kiai, and also students with the general public have taken advantage of the existence of social media.

Iain Madura Postgraduate Director, Dr. Zainuddin Syarif considers social media (medsos) to be a trend as well as a new face in political communication built by the community, including among students (Arifin, 2019). Mobilization, support and political communication built by the community including santri groups in the political contests of district elections, provinces to presidential elections. Done through various types of social networks, such as facebook, whatsapp, instagram and several other accounts. The account network is formed in communities or groups such as peers, working groups, ustadz groups (teachers), alumni generations in schools, boarding schools and universities, and groups of similar support groups and political choices. Conflict in the medsos of santri groups in political contests is a new phenomenon because it undermines the established tradition of boarding schools that have been known by the tradition of civility and obedience as a reflection of akhlaq al-karimah.

The phenomenon of uneavoidable boarding school alumni is also inevitable. There is a pattern of behavior of boarding school alumni that does not reflect what it should be (Susanto \& Muzakki, 2017). These behaviors include not wearing a headscarf in daily life, drinking alcohol and the like, taking drugs, not hesitate to steal things that do not belong to them, prioritizing personal egos over the interests of others in daily life, even leaving prayer and fasting is a common sight for them.

Deputy Governor of Central Java Taj Yasin Maimoen said the tagline of the current santri is ngaji to kiai and habaib, ngaji in boarding schools (ponpes) not on google. Students should also be able to restore the position of religion to solve problems, not make it a problem (humas.jatengprov.go.id, 2019). Furthermore, he explained that Kiai and Habaib in Indonesia scientifically have sanat up to the Prophet Muhammad SAW. Let's maintain and voice that learning should be to Kiai who has sanat up to the prophet. Santri nusantara was still 'gondhelan dateng kiai'.

Leadership in Islamic educational institutions influences the environment in realizing the vision and mission, including leadership in boarding schools. The success of a leadership depends on one's leadership style (Iswiyanto, 2017). The continuity of boarding schools is inseparable from the success of caregivers (kiai) in managing boarding schools. Not a few boarding schools that have adopted modern management in order to keep up with the times. However, not a few boarding schools still use traditional style leadership models. Because the leadership model in boarding schools is unique and has a distinctive character.

Leadership in boarding schools is attached to kiai. Kiai leadership is individual-collective with a spiritual-charismatic leadership style (Prabowo, 2016). Furthermore, he explained that the strength of kiai leadership lies in the charismatic kiai person, so that the kiai individual in pesantren dominates his role more. Kiai has absolute authority in decision making and policy although in some ways kiai remains democratic.

Kiai's charismatic leadership is a leadership that is awarded the Almighty and a leader who has charisma is considered to have supernatural abilities, which can motivate his followers willing to sacrifice for an idea and idea of a leader (Ansor, 2014). Kyai is the most important figure (key person) and decisive in the development and management of boarding schools. So that a kyai is required to be able or good at implementing leadership strategies for the advancement of pesantren or educational institutions led by him (Aziz, H. \& Taja, 2016).

Based on silaturahim and interviews with the nanny of boarding school as salafy Al Asror obtained some problems experienced by the service partner. The partner problems in question are as follows. First, there is a change in the behavior of students associated with the use of smartphones and the internet. Smartphones become a more attractive device for students everywhere to do activities. If it is not controlled then it will be very disruptive to the learning process in boarding schools. Communication patterns between students and students with kiai (ustadz) have also 
changed. Second, the communication pattern of parents to boarding schools has shifted slightly. There are demands from parents of students are quite high. In the past, parents of students were very resigned to activities in boarding schools. However, at this time the parents of the students do not behave as such. Boarding schools must be more transparent and accountable in managing pesantren, especially the main activities. Parents expect the openness of information needed about the development of their son or daughter during their studies at the boarding school.

These two problems become very vital and must be immediately sought solutions. So there is no case of angry parents santri against boarding school caregivers some time ago. Teachers and caregivers in boarding schools must be equipped with a leadership pattern that is responsive and adaptive to the development needs of today's times. The characteristics of today's students cannot be equated completely with the characteristics of students in the past, especially about tawadhu attitude, caring, diligent, politeness, simplicity, and so forth.

In addition to these two problems, boarding schools also face challenges in the future. Students are required to be more able or have competence to be better prepared when entering the community life. The leadership capacity of teachers (ustadz, caregivers, kiai) will have a direct impact on the formation of the character of the students.

Based on the description, the partner problems that will be solved in this devotional activity are: How to improve the leadership competence of boarding school teachers through Leadership Training.

\section{METHOD}

The solution to the problems offered by the team of service is the improvement of the leadership competence of the teaching staff through The Growing Leadership training. Hopefully, teachers will be able to manage the problems in pesantren in a more comprehensive and organized based on modern management and typical pesantren leadership patterns.

The model of implementation of devotional activities is the implementation of training for teachers in boarding schools (kiai, caregivers, ustadz / ustadzah). The methods used are simulation methods and problem-based learning methods. Two methods are expected to provide provision and experience for objects of devotion in dealing with problems in boarding schools. The implementation of this devotional activity is depicted in figure 1 below:

Figure 1.

Methods of Service Implementation

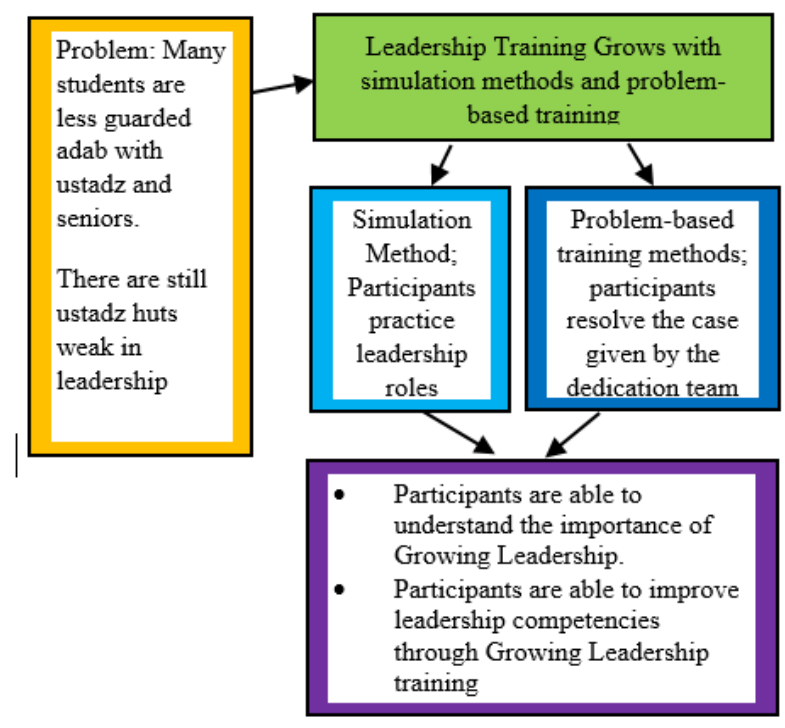

\section{RESULTS AND DISCUSSIONS}

This community service activity was held on August 8, 2020 in madrasah Aliyah Al Asror hall, Patemon Village, Gunungpati District, Semarang City. This activity was attended by teachers and asatidz council in Al Asror Foundation Semarang. The description of the stages of implementation of this devotional activity is as follows:

\section{Activity Planning Stage}

The dedication team prayed and coordinated with the chairman of the Foundation, $\mathrm{KH}$ Almamnukhin Kholid to prepare the activities well. Previously the dedication team has coordinated in the framework of the implementation of devotional activities. The results achieved at the time of coordination, the Foundation wants the service activities to be carried out offline while maintaining health protocols. Handwashing is provided and participants wear masks. Participants of the activity were teachers paud, MI, MTs, MA, SMK and asatidz ponpes Al Asror council, a total of 120 people. Activities will be held in the hall ma Al Asror. The event will be held on August 8, 2020.

Therefore, the form of activity became a seminar with the theme of Leadership Strategy to Grow in Facing Challenges in the Digital Era. This theme is very precise with the concept of Growing Leadership that is being developed by the rector of UNNES and also online learning during the covid-19 pandemic. The dedication team also determines the resource persons in accordance with the results of coordination, namely plt. Vice Rector for Cooperation and Planning, Dr. Hendi Pratama, MA. and Chairman of LP3, Dr. Ngabiyanto, M.Si. Both speakers are leaders at UNNES who have experience in leadership.

Coordination of the service team continued by contacting the resource person and finally this devotional activity in collaboration with LP3 UNNES. 
Al Asror Foundation is a cooperation partner of LP3 so it is appropriate that this activity is carried out jointly.

\section{Stage of Implementation of Activities}

This devotional activity became a cooperation activity between the Faculty of Economics, LP3, and Al Asror Foundation. The activity was attended by 120 teachers and the asatidz council. The details appear in table 1 below:

Table 1.

List of Details of Community Service Participants

\begin{tabular}{rlc} 
No. & \multicolumn{1}{c}{ School Name } & $\begin{array}{c}\text { Number of } \\
\text { Participants }\end{array}$ \\
\hline 1. & PAUD Al Asror & 5 \\
\hline 2. & MITQ Al Asror & 3 \\
\hline 3. & MTs Al Asror & 35 \\
\hline 4. & MA Al Asror & 30 \\
\hline 5. & SMK Al Asror & 25 \\
\hline 6. & Pondok Pesantren Al Asror & 20 \\
\hline 7. & Yayasan Al Asror & 2 \\
\hline & Jumlah & $\mathbf{1 2 0}$ \\
\hline
\end{tabular}

Devotional activities in the form of educational seminars are carried out with the following arrangements of events;

a) Opening

b) Singing Indonesia Raya Song.

c) Remarks from UNNES Representative, By The Head of LP3 UNNES.

d) Speech of the Chairman of the Foundation as well as prayers, by KH. Almamnukhin Kholid.

e) Submission of the first material, by Dr. Ngabiyanto, M.Si.

f) Delivery of the second material, by Dr. Hendi Pratama, MA.

g) Question and answer

h) Closing.

Figure 2.

Chairman of the Foundation, KH. Almamnukhin Kholid gives a speech

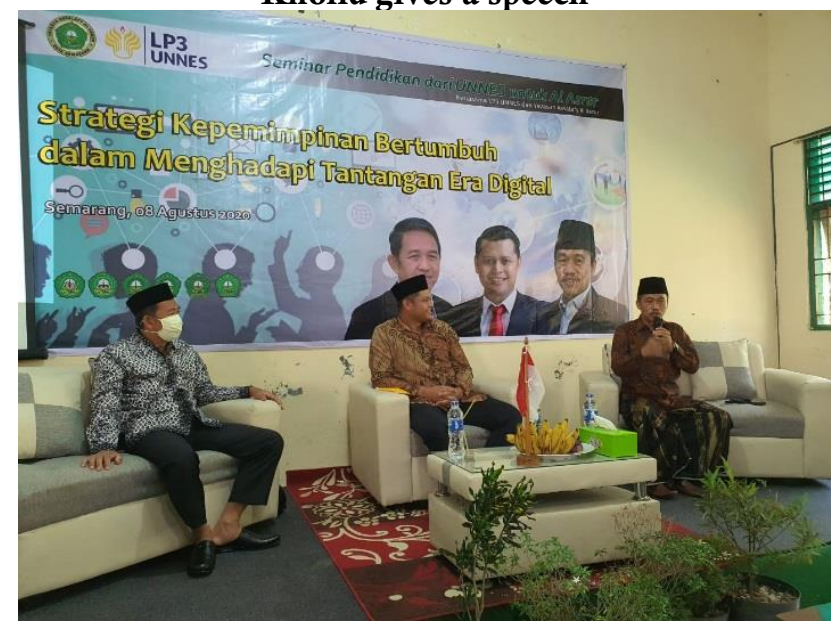

The activity began with the opening by the host, Sister Aisha and continued by singing the song Indonesia Raya. The Chairman of LP3 gave an introductory speech and continued the speech as well as prayers by the chairman of the Foundation, $\mathrm{KH}$. Almamnukhin Kholid. Previously, a document has been signed for the implementation of activities by FE UNNES with Al Asror Foundation. This document is a follow-up to the existing MOU document between UNNES and Al Asror Foundation.

The core activities were guided by moderator, Mr. Drs. Fachrurrozie, M.Si., lecturer of Faculty of Economics. The first speaker, Dr. Ngabiyanto, M.Si. delivered the material "Leadership Strategy to Grow in Facing the Challenges of the Digital Era". The speaker explains the concept of leadership in general and then outlines the concept of growing leadership. The source also explained the importance of growing leadership in the face of a challenging Digital Era. The second speaker, Dr. Hendi Pramata, MA presented material on "Strengthening the Personal Reputation and Institution of Al Asror". He stressed the importance of shaping the Reputation of the Institution and personally to be more aligned. He also expressed how to use social media to build a reputation for the interests of the Institution. He also gave an example of how to build a personal reputation to benefit the Reputation of the Institution.

Participants of the activity are very enthusiastic to participate in this activity. This is evident in the participation of participants when the speaker invites direct dialogue with the participants. Participants were also very enthusiastic at the question and answer session. The activity ends at 12:30 p.m. and closes with a shared photo.

Figure 3.

Speaker Dr. Ngabiyanto, M.Si. delivered the material

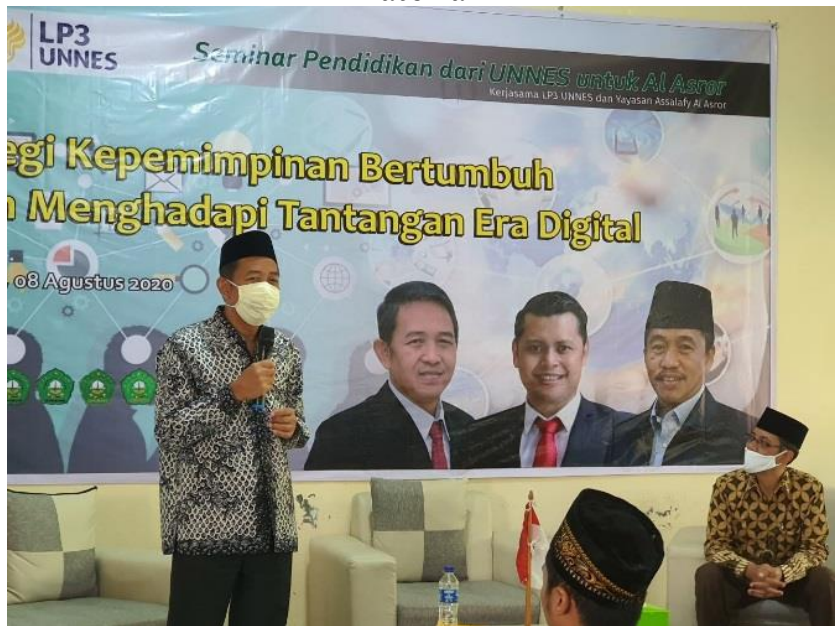

\section{Activity Evaluation Stage}

Evaluation of devotion activities is carried out to see the success rate of the implementation of devotion since the planning stage. Judging from the results of the coordination of the dedication team with the Al Asror Foundation, the planning stage of the devotional activities is good. This is because the service team has performed devotional activities in the previous year so that cooperation has been established well. 
Communication patterns of the service team with the Foundation can also run well and smoothly.

Evaluation at the implementation stage can be seen from several indicators, including the level of attendance of participants, participation of participants, and increased knowledge and understanding of participants. Judging from the indicator of the attendance level of participants, this devotional activity was successfully carried out because $100 \%$ of participants were present at the event. Participants consider this activity very important. The participation rate of the participants also shows the success of devotional activities. Participants are very enthusiastic to participate in the activity from the beginning until the completion of the activity. However, there are participants who leave the activity before the completion of the end.

Figure 3.

Participants Ask Questions

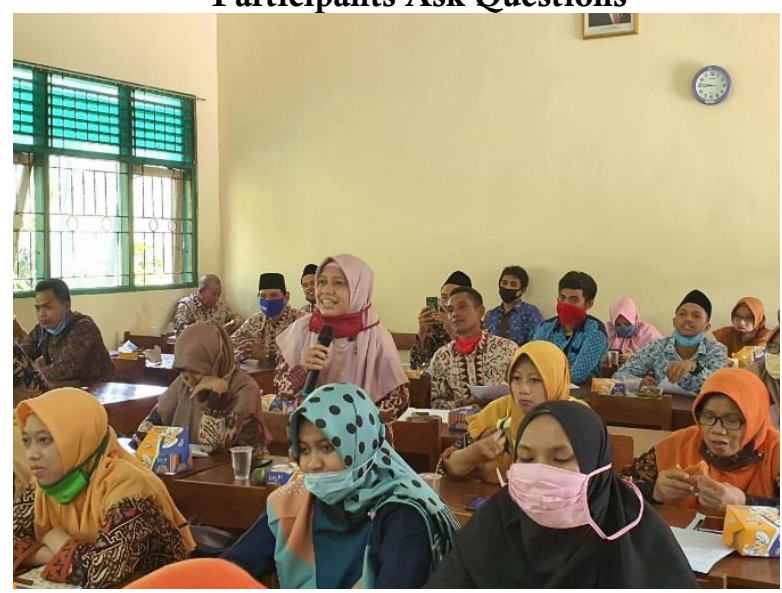

Evaluation of participants' understanding can be seen during the exposure of the material. Material about growing leadership is first known by participants. So the participants have not understood before. So is the second material on how to build a personal and Institutional reputation. Participants have prior knowledge. The speaker invites dialogue and provides concrete examples. And finally participants have a better understanding.

\section{CONCLUSION}

The service activity "Improvement of Teacher Leadership Competency in Boarding Schools Through Growing Leadership Training" in general went smoothly. The activity began with the signing of a document on the implementation plan of activities between FE UNNES and Yayasan Al Asror Semarang. Both speakers delivered the material well, namely Dr. Hendi Pratama, MA. (Plt WR 4 UNNES) and Dr. Ngabiyanto, M.Si. (Chairman of LP3 UNNES) with moderator Drs. Fachrurrozie, M.Si. (Lecturer of FE UNNES). Participants of the activity are very enthusiastic to participate in activities and actively participate in devotional activities. The understanding of leadership grows for the better because it is newly introduced. Participants are also able to improve their understanding of building a reputation for themselves and the Institution. The advice that can be given in the implementation of this community service activity is the sustainability of the activity. That is, the activity does not stop at one activity only. The dedication team can carry out further activities so that the understanding of participants will be better.

\section{REFERENCES}

Ansor, A. S. (2014). Manajemen Pendidikan Islam Tentang Kepemimpinan Kiai Di Pondok Pesantren. Jurnal Pendidikan Islam, 3, 397-407.

Arifin, S. (2019). Medsos sebagai Wajah Baru Komunikasi Politik Santri. Beritajatim.Com.

https://beritajatim.com/pendidikankesehatan/medsos-sebagai-wajah-barukomunikasi-politik-santri/

Aziz, H. \& Taja, M. (2016). Kepemimpinan Kyai dalm menjaga pesantre. Ta'dim Jurnal Pendidikan Islam, $V(1), 9-18$.

Faris, A. (2015). Kepemimpinan Kiai Dalam Mengembangkan Pendidikan Pesantren. 'Anil Islam, 8(1), 123-144.

humas.jatengprov.go.id. (2019). Gus Yasin : Santri Itu Ngaji kepada Kiai dan Ponpes, Bukan Google atau Youtube. Humas.Jatengprov.Go.Id. https://humas.jatengprov.go.id/detail_berita_gu bernur?id=3484.

Iswiyanto, H. A. (2017). Gaya Kepemimpinan Mudîr Dalam Pengelolaan Pondok Pesantren Tahfizhul Qur'an (Studi Kasus Pada Pondok Pesantren di Kota Balikpapan Provinsi Kalimantan Timur). UIN Antasari.

Prabowo, N. (2016). Model Kepemimpinan di Pondok Pesantren Al-Baqiyatush Shalihat Kuala Tungkal Jambi. UIN Sunan Kalijaga.

Susanto, H., \& Muzakki, M. (2017). Perubahan Perilaku Santri (Studi Kasus Alumni Pondok Pesantren Salafiyah di Desa Langkap Kecamatan Besuki Kabupaten Situbondo). Istawa: Jurnal Pendidikan Islam, 2(1),
https://doi.org/10.24269/ijpi.v2i1.361 